\title{
MAMITA YUNAI: LA LITERATURA DEL COMUNISMO COSTARRICENSE COMO PARTE DE UNA VANGUARDIA POLÍTICA
}

Vanessa Pietras

\author{
Recibido: 16/05/2015 Aceptado: 13/07/2015
}

\begin{abstract}
Resumen
La vanguardia política costarricense es un caso excepcional en Centroamérica porque se manifiesta a través del "Comunismo a la tica". No obstante, su importancia radica en la formación de políticas sociales mediante una alianza estratégica entre el Partido Comunista, la Iglesia católica y el expresidente Dr. Calderón Guardia. Esta vanguardia política inicia su difusión por medio del realismo social descrito en la novela Mamita Yunai, en 1941, y por las proclamaciones comunistas dirigidas por Carlos Luis Fallas en 1955 sobre la huelga bananera.
\end{abstract}

Palabras clave: vanguardia política; comunismo a lo tico; Mamita Yunai; realismo social; racismo; antiimperialismo.

\begin{abstract}
The Costa Rican political avant-garde was a unique case in Central America because of the "Tico's Communism". Its importance depended on the establishment of social policies through strategic alliances with the Communist Party, the Catholic Church, and the Government of Dr. Calderón Guardia. The Costa Rican political avant-garde grew because of the social realism described in his novel Mamita Yunai in 1941, and by the communist proclamations delivered during the banana strike led by Carlos Luis Fallas in 1955.
\end{abstract}

Key words: Costa Rican political avant-garde; “Tico's Communism”; Mamita Yunai; social realism; racism; anti-imperialism.

\section{Introducción}

El presente ensayo está formado por diferentes secciones que permiten dar una amplia perspectiva del vanguardismo político costarricense. En primer lugar se describe al principal actor, el Partido Comunista Costarricense desde su origen en Costa Rica tanto a nivel interno como a nivel internacional. En segundo lugar, se explica la relación del comunismo con el sistema económico establecido en esa época en ese país. En tercer lugar, se expone la alianza estratégica entre el Partido Comunista, el 
gobierno del presidente Calderón y la Iglesia católica. Y en cuarto lugar, se presenta el vanguardismo político analizado desde una perspectiva literaria comunista por medio de la novela Mamita Yunai.

El comunismo en Costa Rica surge en 1931 con la formación del Partido Comunista de Costa Rica (PCCR) y termina en 1948 con la administración de Figueres Ferrer, quien declara ilegal el comunismo en el país. Para explicar el desarrollo de ese movimiento, Iván Molina señala que este fue tardío, pues “La expansión inicial del comunismo en Centroamérica ocurrió después de 1920, influida por activistas extranjeros - principalmente mexicanos- y por la propaganda enviada por el Comintern" (2009: 62). Sin embargo, Molina argumenta que la crisis económica mundial de 1930 y las dictaduras en Centroamérica permitieron el desarrollo del comunismo en Costa Rica, y en 1931 nace el PCCR. En ese sentido, el país fue una excepción a nivel centroamericano, ya que se convirtió en el único que permitió legalmente el comunismo:

El ascenso a la presidencia de la república de Ricardo Jiménez (1932-1936), quién [sic] desde que fue candidato se pronunció a favor de la legalización electoral de los comunistas, permitió que el PCCR, tras cambiar su nombre a Bloque de Obreros y Campesinos (BOC), pudiera finalmente inscribirse y competir (Molina, 2005: 409-410).

Así, el Partido Comunista se forjó bajo una tendencia democrática y legalizada, y además promovió el vanguardismo soviético a través de sus publicaciones en el periódico Trabajo. No obstante, el Partido Comunista presenta diferencias ideológicas con respecto a las doctrinas de la Tercera Internacional Comunista, conocida como la Comintern. Por tal razón, historiadores costarricenses como Molina, Solís, Díaz, entre otros, lo llaman "Comunismo a la tica". De acuerdo con Eric Hobsbawm, la Internacional Comunista permitía variaciones locales entre países y esto diferenció el comunismo costarricense con el del resto del mundo: "existía en esa época una tendencia subjetiva, de variación local, y de desarrollo interno en el lineamiento del comunismo internacional siempre y cuando esa tendencia interna no se impusiera en el país de forma obligatoria" (2011: 264). Esta directriz permitió distinguir la ideología comunista en Costa Rica y adaptarla al contexto local. De ahí surgieron ideas y reformas que luego dieron origen al "Comunismo a la tica".

Ana María Botey y Rodolfo Cisneros, en La Crisis de 1929 y la Fundación del Partido Comunista de Costa Rica, exponen que la política funcional de ese partido debía estar dirigida por la clase trabajadora. En cuanto a la defensa y previsión social, el comunismo proponía el establecimiento de seguros sociales a cargo del Estado, para la desocupación, accidentes de trabajo, enfermedades en general, vejez y maternidad, así como la ley de organización sindical y el derecho a la huelga. Este partido abogaba por la emancipación jurídica de la mujer, la revisión de contratos y convenios por el Estado con el capitalismo nacional y extranjero (Botey y Cisneros, 1984). El “Comunismo 
a lo Tico" logra entonces separarse ideológicamente de las ideas de la Tercera Internacional Comunista y adaptarse al contexto costarricense. En este ensayo se destacan cuatro diferencias ideológicas entre el Partido Comunista y la Comintern, que se explican a continuación.

La primera discrepancia fue la legalización del Partido Comunista en Costa Rica. El PCCR cambió su nombre dos veces, pues pasó de ser Partido Comunista de Costa Rica (PCCR) a Partido del Bloque de Obreros y Campesinos (BOC) en 1932, con la finalidad de participar en las elecciones populares, y posteriormente se convirtió en el Partido Vanguardia Popular (PVP) debido a la influencia de la Iglesia católica, en especial de Monseñor Sanabria en 1943. A pesar de las variaciones en su nombre, el Partido Comunista mantuvo su carácter legal en el país, conservó intactos sus miembros, continuó con la publicación del periódico Trabajo, y no produjo ninguna transformación ideológica ante los cambios de sus denominaciones.

La segunda diferencia que presenta el Partido Comunista es el respeto por la democracia y el voto popular. Costa Rica estaba a favor de las elecciones democráticas presidenciales cada cuatro años, y las votaciones de diputados y munícipes cada dos años. Este país estaba en desacuerdo con la dictadura del proletariado, y como Manuel Mora, fundador y secretario del Partido, menciona: "No somos enemigos del régimen democrático. Por el contrario, lo sostendremos y lo defenderemos en la medida de nuestras posibilidades" (Merino del Río, 1996: 49). Es decir, el Partido Comunista se adaptó a la democracia costarricense y no apoyó la dictadura del comunismo propuesta por la Comintern.

La tercera desigualdad corresponde a la Revolución Agraria y Antiimperialista. Costa Rica no estaba a favor de la propiedad pública. Por el contrario, el PCCR creía y mantenía su posición en defensa de la propiedad privada. Esta diferencia ideológica fue apoyada por Manuel Mora: “Nos oponemos resueltamente al trasplante a nuestro país de fórmulas que no calcen en nuestra realidad económica, social y política" (Merino del Río, 1996: 49). Además, él sostenía que: “No somos enemigos de la pequeña propiedad, sino de la propiedad que se forma, precisamente, mediante la eliminación de la primera y mediante el robo en sus diferentes aspectos"' (Merino del Río, 1996: 50). Por tanto, el Partido Comunista respetaba la propiedad privada en minifundios, pero reclamaba la participación de la inversión extranjera en el territorio costarricense en forma de latifundios, específicamente en el caso de Limón con la inversión extranjera.

Estas diferencias ideológicas del Partido Comunista fueron únicas, internas y locales, y provocaron un desacuerdo ideológico con la Tercera Internacional Comunista. De acuerdo con Rodolfo Cerdas Cruz, los dirigentes de la Comintern criticaban frecuentemente a ese partido debido a su falta de celo revolucionario y de comunicación por escrito. Además, según este autor, los líderes del Partido Comunista costarricense pidieron enérgicamente consejos y apoyo material de la Comintern, como dinero y literatura, pero esta no se los proporcionó. 
En 1933, el Partido Comunista solicitó la membresía en la Comintern, pero la solicitud fue rechazada. Sin embargo, las relaciones entre el Partido Comunista y la Comintern mejoraron después de 1934 debido a un cambio ideológico de esta, ya que "para el año 1934, cada país practicante del Marxismo tenía la libertad de adaptar el modelo comunista a sus propias condiciones y sus necesidades internas permitiendo una transformación ideológica y de esta manera facilitar el desarrollo popular de las normas comunistas" (Hobsbawm, 2011: 264). A raíz de este cambio ideológico de la Tercera Internacional Comunista, Costa Rica presentó ante la Comintern la problemática social de los afrocaribeños y los movimientos revolucionarios sindicalistas producidos en 1934 y dirigidos por Fallas, quien era miembro del partido. Esto le permitió al Partido Comunista superar las divisiones ideológicas con la Comintern. Pero no fue hasta 1935, en el VII Congreso de la Internacional Comunista celebrado en Moscú, cuando Costa Rica se adhiere oficialmente a la Comintern con la participación del delegado Rodolfo Guzmán.

La cuarta diferencia surgió en 1943 con la alianza estratégica entre el gobierno del presidente, Dr. Rafael Ángel Calderón Guardia, la Iglesia católica con Monseñor Manuel Sanabria y el Partido Comunista con la participación del secretario del partido Manuel Mora. Es decir, con el gobierno de Calderón se produjo una alianza atípica entre comunistas y católicos, una nueva perspectiva a nivel nacional e internacional en la historia centroamericana. Esta alianza debe estudiarse detalladamente, ya que los comunistas y la Iglesia católica mantuvieron sus filosofías, lo cual les permitió conservar su oposición ideológica. Pero lo que sí se logró en esa alianza fue unificar la política social y mejorar la calidad de vida de los obreros costarricenses. Es decir, los actores tenían un objetivo en común, la justicia social y las garantías de los trabajadores.

Sin embargo, esta alianza fue compleja, por lo que para poder explicar los vínculos entre esos actores es necesario analizar la relación del presidente Calderón con la Iglesia católica y, posteriormente, exponer el vínculo con el Partido Comunista. Primero, esta unión se constituye debido a que el gobierno de Calderón desarrolló el cristianismo como el pilar fundamental de la identidad y de la nacionalidad costarricense en esa época:

Un factor fundamental que opera en esta dinámica social, politica y económica fue la Iglesia Católica. En la vida política costarricense desde hacía muchos años se había establecido como especie de norma, que para poder impulsar candidaturas o proyectos de gran envergadura se necesitaba el apoyo del capital del gobierno y de la Iglesia Católica. (Contreras, 1988: 181).

Este enfoque adquiere su validez a través de la historia costarricense, la cual demuestra una estrecha relación entre el Estado y la Iglesia católica desde tiempos coloniales. Según Gustavo Adolfo Soto Valverde, en el libro La Iglesia Costarricense y la Cuestión Social: Antecedentes, Análisis y Proyecciones de la Reforma Social Costarricense 
de 190-43, fue necesario delimitar las reglas entre estos actores para no confundir sus funciones: "Un pueblo arraigado en sus tradiciones religiosas y profundamente católico necesita la definición de esas relaciones" (Soto, 1985: 44). Sin embargo, a pesar de que la Iglesia logró separarse del Estado debido a las reformas liberales entre los años 1880 y 1884, esta pareciera adquirir fuerza debido a la formación del Partido Unión Católica en 1889:

... por las necesidades de los tiempos es indispensable que los católicos estrechemos los santos lazos que nos unen y compactemos nuestras filas, para trabajar eficazmente en pro de los intereses de nuestra sagrada Religión intimamente ligados con los de la Patria. [84] (Soto, 1985: 74).

No obstante, en 1940, cuando Calderón llega al poder, la Iglesia católica logra una posición de privilegio principalmente al emplear el cristianismo social en su gobierno: "Comprendí, desde el primer instante, que el movimiento Cristianismo Social, que había condensado la Encíclica de León XIII y el Código de Malinas, contenían las fórmulas más aplicables a nuestra realidad inmediata, si se interpreta esta lealmente. [75]" (Soto Valverde, 1985: 184). Mas aún, las Reformas Sociales en Costa Rica fueron amparadas por las doctrinas y enseñanzas de la Iglesia católica, particularmente de los pontífices León XIII y Pío XI.

La Iglesia católica tenía presencia y autoridad moral en la sociedad costarricense. Un ejemplo de esto es el caso del cambio de nombre del Partido Comunista: "La Iglesia Católica Costarricense autoriza a los católicos que lo deseen a militar en el nuevo partido. Se celebró un Congreso del Partido y adoptamos el nombre de Vanguardia Popular, fue una condición impuesta por Mons. Sanabria" (Contreras, 1988: 62). Lo anterior revela que la Iglesia tenía cierta influencia en Costa Rica.

Sin embargo, a pesar de esa intervención, los comunistas nunca adaptaron los principios cristianos de la Iglesia católica: "No tenemos como entidad social credo religioso ni antirreligioso" (Merino del Río, 1996: 49). Por ende, lo que se dio en esa época fue un acercamiento político en el reconocimiento de los problemas que afectaban económica y socialmente al país entre los actores. Soto Valverde ejemplifica esa afirmación:

Y bien se expresa Carlos Luis Fallas cuando dice: “... en medio de la acongojante situación socioeconómica originada por la crisis, sólo se escuchó como único rayo de esperanza, la voz de la Iglesia Católica Costarricense... inspirada en los principios de la Rerum Novarum. [118] (1985: 86).

Así, se crea una conciencia política entre los líderes religiosos y los comunistas que busca ayudar y proteger al costarricense por medio de las ideas de justicia social a los trabajadores que viven en la pobreza y que sufren los efectos negativos de la mala distribución del capital y de la diversificación de las clases sociales en Costa Rica. 
No obstante, la alianza entre el presidente Calderón y la Iglesia católica produjo una alteración en el término democracia en Costa Rica, ya que esta, según Octavio Paz, se obtiene con la separación de la Iglesia y el Estado, la libertad de creencias, opiniones y asociación. Es decir, la Iglesia católica altera de forma indirecta el concepto de democracia expuesto por Paz al tener la autoridad moral para actuar contra el partido comunista:

Ningún otro grupo fue atacado tan fuerte e intensamente por la Iglesia como lo vivieron los comunistas. El Comunismo, por su parte, fue visto como una débil institución que trataba de establecerse por sí misma; mientras que el catolicismo era fuerte en Costa Rica. El comunismo mostraba cautelosamente campañas antirreligiosas con algunas excepciones de sus seguidores. Más, sin embargo, [sic] los comunistas tuvieron muchas veces que retractarse de sus decisiones debido a la influencia de la Iglesia y en varias ocasiones, estos votaron a favor de la Iglesia solo para aprobar la Reforma Social. (Biesanz, 1944: 220).

Por tanto, al contar con el patrocinio del Estado, la Iglesia católica demostraba una intensa crítica ideológica contra el comunismo en el país. Pese a esto, Costa Rica compensa esa debilidad al permitir la libertad de creencias y de asociación. Y esto se observa con el Partido Comunista, el cual mantiene su legalidad en el país. Esto permite analizar el caso costarricense de forma única debido a que se puede estudiar el comunismo dentro de la democracia costarricense en esos años.

Históricamente, esta relación entre la Iglesia católica y el Partido Comunista fue muy difícil y complicada. Las discrepancias entre la Iglesia católica y el Partido Comunista fueron opuestas en su ideología. Por una parte, la Iglesia católica buscaba imponer sus ideas de cristiandad (ayudar al necesitado; es decir, aceptaba indirectamente la división de clases sociales: ricos y pobres). Pero, por otro lado, el Partido Comunista exploraba la idea de un cambio en la reforma social imponiendo la justicia social de una forma equitativa sin importar las clases sociales. No obstante, debido a la aprobación del Rerum Novarum como una alternativa social, la Iglesia católica y el Partido Comunista lograron unificar un objetivo en común para ayudar al trabajador, la clase marginada costarricense. De acuerdo con Molina, en su libro Anticomunismo Reformista, "la Iglesia católica no tolera ni ha tolerado nunca enseñanzas ni prácticas específicamente comunistas... Nadie puede dudar que el comunismo es un sistema erróneo, peligroso precisamente por el contenido de justicia y equidad que se halla en su aservo [sic] doctrinal" (2007: 141). Como se puede observar, la Iglesia discrepaba del comunismo en Costa Rica. No obstante, la alianza estratégica logra establecerse debido a la participación activa del Monseñor Sanabria, quien pudo defender al comunismo y persuadir ideológicamente a sus oponentes: 
Yo estableci amistad con una agrupación de costarricenses que apoyaron una politica social mía, por considerarla buena, sin pedirme que yo me adhiriera a ninguna filosofía contraria a la que yo sustento. Más concretamente: Vanguardia Popular y yo coincidimos en ciertas cuestiones concretas: Garantías Sociales, Código de Trabajo, Seguros Sociales, leyes de tierras. Estas cuestiones, o tesis sociales para darles la nominación más justa, encajaban dentro del programa de los vanguardistas y también dentro del marco de mis convicciones y de mis planes de Gobierno (Molina, 2007: 146).

De esta forma, la relación entre los católicos y los comunistas se consolidó debido a que estos actores decidieron trabajar en conjunto por el beneficio del país y dejar de lado sus diferencias. Sin embargo, la defensa del territorio nacional fue prioridad para el Partido Comunista y su ideología antiimperialista promovió la lucha social contra las inversiones extranjeras, aspecto que se explica a continuación.

\section{Formación del capitalismo en Costa Rica y su relación con el comunismo}

El surgimiento del capitalismo costarricense de los años treinta nace principalmente con el desarrollo industrial de la oligarquía cafetalera en la Meseta Central y las inversiones extranjeras estadounidenses del banano en el Caribe de Costa Rica:

A pesar de que hayan existido antecedentes coloniales significativos (como por ejemplo, la cría del ganado, la caña de azúcar y el cultivo del tabaco) la producción de productos primarios para el consumo familiar en el Valle Central de Costa Rica y la exportación del producto al mercado externo fueron los principales componentes económicos a larga escala que permitieron el desarrollo y la expansión agraria del capitalismo en Costa Rica... La distancia territorial entre los granjeros permitió que la producción de la mercadería en ese país fuera algo más que el consumo. Fue más que un pasado pre capitalista en un mercado mercantilista; fue el resultado histórico de una economía de acumulación del capital que tomó lugar en la sociedad rural de esa época (Samper, 1990: 3).

Aunque la producción agraria era la principal fuente de ingresos económicos en el país, existía una gran división interna en aspectos sociales y económicos entre productos agrícolas. En consecuencia, la producción y exportación del café en Costa Rica beneficiaba a la población al promover el crecimiento económico y social debido a la participación de pequeños y medianos productores en la economía costarricense. Es decir, el capital del café se reinvertía en el suelo nacional. Mientras que la producción del banano, en la provincia de Limón, produjo una modificación estructural: el cambio del minifundio (pequeños agricultores) al latifundio (concesión territorial). De esta forma, la producción del banano era cien por ciento de inversionistas extranjeros, principalmente de los Estados Unidos. Y, por tanto, el beneficio económico del producto no fue reinvertido en territorio costarricense. 
El idioma empleado en la producción del café y el banano era una diferencia significativa. En los minifundios del café se hablaba español mientras que el idioma inglés era frecuente en los enclaves del banano. De acuerdo con Bourgois, debido a esta diversidad del lenguaje: "Había una profunda enemistad racial entre Hispánicos (españoles) y negros, y esta les impedía desarrollar solidaridad entre ellos; el leguaje era también una limitación ya que ninguno de estos grupos sociales hablaba el mismo idioma" (1989: 59). Como se puede apreciar, el lenguaje generaba una diversificación entre la población costarricense que produjo una división socioeconómica y una discriminación cultural.

Otra disimilitud fue el color de piel de los peones, elemento históricamente determinante para generar división racial. Por un lado, los trabajadores del café eran descendientes de españoles y mestizos, mientras que la población que trabajaba en las bananeras era predominantemente negra, pues la mayoría llegó de Jamaica. Según Bourgois, "el proceso de experimentación con varias razas terminó en 1890 y se determinó que los mejores trabajadores fueron los negros del Caribe, pues eran quienes se les podían explotar más" (1956: 48). Aunque este autor señala que Minor Keith, dueño de la United Fruit Company, había importado trabajadores de distintas nacionalidades: chinos, italianos, canadienses, suizos, turcos, indios, egipcios, entre otros, la mayoría de los inmigrantes que trabajaban en las bananeras provenía del Caribe. Esto provocó segregación social y discriminación racial en Costa Rica principalmente entre la raza blanca y negra.

Como las inversiones extranjeras no aportaban beneficios al país, el Partido Comunista enfocó su participación política a la lucha antiimperialista de las inversiones extranjeras y el comercio del banano. Y para ello Fallas utilizó la estrategia política de unir a al grupo de trabajadores blancos y negros. Es decir, la visión orgánica de Fallas se proyectó en las ideas antiimperialistas.

A pesar de que la United Fruit Company, con su participación en Costa Rica, creaba ciudades cosmopolitas, construía carreteras y ferrocarriles para el transporte comercial del banano y del café, la UFCO también mostró efectos contraproducentes como: la explotación laboral, el problema de distribución del capital en manos extranjeras, la migración hacia la costa caribeña tanto de nacionales como de extranjeros, la discriminación racial y las divisiones por motivos vinculados al idioma, entre otros aspectos. Todo esto constituyó un baluarte para el sindicalismo y, especialmente, para el Partido Comunista en su lucha social contra el racismo y el imperialismo estadounidense: "El Partido Comunista... gracias a su quehacer editorial (en especial la publicación de Trabajo), supuso una verdadera novedad en la política costarricense en las décadas de 1930 y 1940" (Molina, 2005: 421). La participación del Partido Comunista empezó a establecer una retórica política en Costa Rica, en donde se exaltó la lucha social para combatir la explotación laboral del capitalista extranjero y defender los derechos de los trabajadores. Las primeras manifestaciones literarias se encuentran en el periódico 
del partido, llamado Trabajo, y posteriormente se refuerzan con la novela Mamita Yunai donde Carlos Luis Fallas presenta una literatura que refleja el realismo social. El autor introduce una ideología socialista y revolucionaria en la Gran Huelga Bananera de 1934. Con esta intervención, el Partido Comunista se convirtió en el segundo partido político de mayor peso del país, pues contaba con el voto popular de la clase trabajadora costarricense. Por tanto, el Partido Comunista inició el desarrollo de una estructura de beneficio social para el trabajador costarricense, aspecto que se considera parte de la alianza política país.

\section{Alianza estratégica}

La unión estratégica del presidente Calderón Guardia, la Iglesia católica y el Partido Comunista (BOC) se produce debido a tres importantes aspectos. El primero corresponde a la política exterior entre los Estados Unidos y la Unión Soviética. Estos países unieron sus ideologías para atacar el fascismo:

La alianza de las potencias mundiales entre Estados Unidos y la Unión Soviética producto de la Segunda Guerra Mundial ayudó a Calderón [sic] establecer sus reformas sociales y facilitó la unión entre el Partido Comunista (quién cambió de nombre al Partido Vanguardia Popular para mejorar su imagen) y el Partido Conservador PRN (Mesa-Lago, 2000: 404).

El segundo aspecto se refiere al desarrollo de una política interna entre Calderón y el Partido Comunista, llamado Caldero-Comunismo. La lucha contra el fascismo permitió que el Partido Comunista (BOC) se acercara ideológicamente a Calderón, quien lo aceptó debido al cambio ideológico del partido al abandonar el ultraizquierdismo. Esta política interna fue desarrollada por Calderón al pronunciarse a favor de tendencias populistas que benefician a la clase media y baja costarricenses.

Y el último aspecto hace referencia a la ideología del cristianismo auxiliada por el Gobierno: “Calderón Guardia en 1940 aproximó nuevamente, de manera práctica y programática, a la Iglesia y el Estado" (Solís, 2013: 127). Esta alianza le concedió a la Iglesia católica la autonomía de modificar el sistema de educación pública costarricense:

Como parte de una revisión general del sistema educativo costarricense, el gobierno de Rafael Ángel Calderón Guardia, quien fue electo en 1940, promovió el programa de reformas educativas. Este cambio favoreció a la Iglesia Católica y le permitió obtener a la Iglesia el control sobre el sistema educativo público. De tal forma que los líderes católicos proclamaron adherir en las escuelas públicas la materia religión como parte del currículo. (Harpelle, 2001: 126).

En suma, Calderón estableció una unión ideológica con la Iglesia católica, pero también creó una alianza estratégica con el Partido Comunista. De esta forma, los tres actores intervinieron en la formación de una estrategia política en Costa Rica, aunque, 
cada uno desde su lugar, se dedicaron a promover la justicia social y sindical en el país. Por un lado, Calderón buscaba establecer las Garantías Sociales, mientras que la Iglesia católica intentaba exponer su catolicismo social. Y, por otro lado, el Partido Comunista (BOC) añoraba establecer ideas sindicalistas para los obreros.

La alianza, llamada el Bloque de Victoria, fue una realidad y la participación de estos actores permitió un cambio en el rumbo social en Costa Rica. Sin embargo, esta alianza fue muy compleja y paradójica, y así lo señala Molina (2008), pues, por un lado, se observa cómo el Partido Comunista promovió el gobierno de Calderón: "Calderón fue nuestro aliado... la alianza con el Dr. Calderón con nosotros tuvo una razón única y fundamental: las leyes sociales" (51). Pero, posteriormente, se aprecia la discrepancia y separación entre esos actores: "El esfuerzo por alejarse cada vez más del PVP, en contraste, era esencial para el calderonismo, dado que en las décadas de 1950 y 1960, dominadas por la guerra fría, demostrar que se era más anticomunista que los adversarios" (Molina, 2008: 57). Es decir, la alianza solo funcionó en un determinado período y con el único propósito de establecer leyes sociales como las Garantías Sociales, el Código de Trabajo, entre otras.

Es importante explicar por qué se da el inicio y el final de esa alianza. Y es que esta nació debido a la influencia de la política externa que afectó la dirección administrativa en Costa Rica. La primera implicación se observa cuando los Estados Unidos y la Unión Soviética crearon una alianza contra el fascismo. Y así, el presidente Calderón y el Partido Comunista lograron establecer una coalición estratégica al declararse ambos en contra del fascismo. Pero luego, estos actores se separaron producto de la política externa mundial al declararse la lucha ideológica entre los Estados Unidos con el capitalismo y Rusia con el comunismo. Entonces, el presidente Calderón apoyó a los Estados Unidos y el Partido Comunista secundó a Rusia. Así, resulta substancial estudiar la política ideológica del Partido Comunista en Mamita Yunai para poder interpretar los ideales socialistas incógnitos en la novela y analizar con detenimiento los elementos del vanguardismo político.

\section{Literatura comunista costarricense vista como vanguardia política}

Al analizar detalladamente la vanguardia en América Latina, se logra descubrir que en estos países se produce, primero, una vanguardia artística para luego desarrollar una vanguardia política. Sin embargo, Costa Rica es un caso único que va en contra de esta tendencia, ya que presenta un movimiento de vanguardia política pero no artística en el sentido estricto de la palabra. En términos artísticos, la vanguardia costarricense no tiene características que se asocien con la vanguardia típica del resto de América Latina, sino que cuanto se explora es un movimiento literario de índole social vinculado con la vanguardia política.

Las vanguardias artísticas y políticas comparten elementos en común como las tendencias anarquistas e izquierdistas, pero, al mismo tiempo, exponen una diferencia 
en cuanto a la forma y al contenido. La vanguardia política busca una transformación social basada en su discurso (forma) y su visión estética de totalidad (contenido). Además, utiliza sus propios recursos estéticos basados en la política y en la lucha social, como se observa en la novela Mamita Yunai escrita por Carlos Luis Fallas. Entonces, la vanguardia política costarricense a nivel orgánico y funcional se ampara en una totalidad (capitalismo a nivel mundial) y no en una fragmentación de esa totalidad (la postura de la vanguardia literaria). Esta ideología encuentra eco teórico con Lukács, quien explica el realismo social como un producto del vanguardismo político ("para conocer detalladamente a un objeto, es necesario descubrir y comprender todos sus aspectos, sus relaciones y sus meditaciones" (Leitch, 2001: 1037). Las obras de índole social realista se proponen abarcar la complejidad por medio de una mediación del lenguaje y $\mathrm{Ma-}$ mita Yunai hace justamente eso: retrata al sistema capitalista en Costa Rica y lo critica, lo cual permite determinar una realidad continua y una visión integral del capitalismo en Costa Rica por medio de la United Fruit Company (UFCO); es decir, Fallas logra acoger una totalidad tanto en su forma como en el contenido político en esta novela.

El concepto de vanguardia en Costa Rica se logra desarrollar plenamente en el sentido político debido al desenvolvimiento de una estética fundamentalmente realista. Como consecuencia, este país presenta un vacío artístico en términos vanguardistas, pero logra compensar esa oquedad con la política. La fuerza política de más peso que llenaría esa concavidad artística y literaria es el Partido Comunista (Partido Comunista de Costa Rica PCCR 1931-1932, Bloque de Obreros y Campesinos BOC 19321943, y Partido Vanguardia Popular PVP 1943-1948), en el cual se destaca la participación de Carlos Luis Fallas, líder sindicalista y al mismo tiempo autor de Mamita Yunai.

Mamita Yunai define la Costa Rica de los años treinta y denuncia la corrupción electoral del Gobierno costarricense, las injusticias en que vivían los trabajadores bananeros y la desigualdad económica y social en cuestiones de género, raza y lenguaje. Además, esta novela condena el abuso del capitalismo por medio de las inversiones extranjeras, específicamente reprocha a la empresa United Fruit Company, símbolo del imperialismo estadounidense en Costa Rica. Al tiempo que reclama la unificación del proletariado para luchar por los derechos laborales, civiles y sociales. Se describen, así, temas candentes de la vanguardia política y se destaca la trascendencia a nivel nacional e internacional, principalmente con temas como la sindicalización laboral en Costa Rica y el establecimiento de garantías laborales dignas para el trabajador.

Simultáneamente, se examina el vanguardismo político en Costa Rica a través de la novela Mamita Yunai. Y esto se observa gracias a la participación activa de Carlos Luis Fallas como autor de la obra, pero también como dirigente sindicalista de la huelga de 1934. Por ende, este novelista logra emplear elementos vanguardistas en la obra debido a su discurso de cambio social (ideología antiimperialista) y a su contenido estético (abuso orgánico del capitalismo). Es decir, Fallas une la doctrina del Partido 
Comunista con la realidad social del Caribe costarricense, con lo cual crea una literatura de índole social-realista.

Mamita Yunai presenta muchos temas que permiten ver una crítica a la cosmovisión capitalista basada en un discurso de cambio social amparado por ideología antiimperialista. Sin embargo, este ensayo analiza, fundamentalmente, el racismo como visión fragmentada, debido a que fue una problemática social de la época en Costa Rica.

\section{Elementos estéticos del vanguardismo en la obra Mamita Yunai}

Mamita Yunai puede considerarse una novela vanguardista porque logra narrar la realidad social costarricense de la época, les da una voz política a los trabajadores y reconoce socialmente la problemática del trabajador costarricense. Al mismo tiempo, esta novela exalta los ideales comunistas y enfoca su lucha contra el imperialismo y el racismo exhibido por las injusticias económicas de las inversiones extranjeras, especialmente la UFCO. Al tiempo que los trabajadores se unen bajo el liderazgo del Partido Comunista, el cual aboga por la igualdad social y racial, aspectos que Fallas envuelven en la novela.

A lo largo de cuatro apartados, Mamita Yunai se basa en una denuncia contra las violaciones de los derechos de los trabajadores, los abusos del poder político y la división de clases sociales. En el primer apartado, Fallas hace una crítica a la corrupción electoral y analiza la forma de vida de los indígenas. En el segundo y tercero, el autor habla acerca de las condiciones inhumanas del trabajador costarricense de piel negra y blanca, principalmente de la United Fruit Company. Y, en la cuarta parte, se refiere al discurso de Carlos Luis Fallas en la Asamblea de Solidaridad de 1955, referente a la Gran Huelga Bananera del Atlántico de 1934. Su discurso permite estudiar la ideología política antiimperialista y anticapitalista del Partido Comunista.

En la obra, Fallas denuncia los abusos de la compañía bananera y declara la explotación y expropiación de la tierra nacional por parte de las empresas estadounidenses. Específicamente, esta novela critica al capitalismo con diálogos dramáticos, teatrales, fragmentos descriptivos y líricos, al tiempo que exalta al trabajador costarricense. Además, el autor, como protagonista de la novela, emplea el autorretrato y el testimonio para denunciar la realidad de Costa Rica en los años treinta y en especial en 1934, con la finalidad de convencer al lector de la realidad costarricense.

La novela utiliza documentos y hechos verídicos del autor. Fallas exhibe su participación como líder político y sus acciones como el haber trabajado como fiscal para las elecciones en Costa Rica, las publicaciones del periódico Trabajo, sus crónicas, datos históricos y el discurso político para reafirmar la veracidad de lo escrito en esta novela. Con esto, el autor busca defender su carácter objetivo y legal como narrador. Además, Fallas logra demostrar la realidad costarricense de esa época por medio de su lucha revolucionaria y con el realismo social: 
En cuanto a los aspectos literarios-estéticos se ha resaltado su arraigamiento histórico en el regionalismo y en la novela criollista, construyendo de este modo toda una serie literaria del realismo social que, pasando por la novela bananera finalmente culminaría en el testimonio (Mackenbach, 2006: 130).

Este novelista usa el realismo social con el fin de acercarse a la realidad costarricense y validar su veracidad en el discurso literario. Esto se ve especialmente en la cuarta parte de la novela, donde se plantea más que una crónica, un discurso público y un testimonio verídico de un dirigente político.

A nivel literario, Mamita Yunai presenta elementos vanguardistas y estéticos propios del regionalismo y el criollismo. Para ello, Fallas utiliza un lenguaje coloquial, pueblerino y vulgar, lo cual le permite acercarse a la clase trabajadora y al pueblo que vive en pobreza económica y discriminación social. Precisamente, una de las estrategias que le permitió acercarse al pueblo costarricense fue este tipo de lenguaje con dichos y refranes propios del habla, dejando atrás el vocabulario fino e intelectual del vanguardismo literario. Por tanto, la principal función de este autor es representar la voz de los trabajadores marginados económica y socialmente. Fallas acusa a la UFCO y exalta los problemas sociales que esta compañía generó en Costa Rica, como la desigualdad económica, las segregaciones culturales (razas, mestizaje) y las condiciones antihigiénicas en la bananera. Así, el autor busca describir una revolución de abajo hacia arriba; es decir, una alteración social de las clases proletarias que luchan contra la clase alta y, en especial, contra las inversiones extranjeras que se estaban apoderando del territorio nacional y explotando laboralmente al obrero.

No obstante, en Mamita Yunai se presenta una narrativa literaria fundamentada en un combate entre el hombre y la naturaleza. Para ello, Fallas utiliza las descripciones que se enfocan en la adversidad que el obrero debe pasar en las bananeras para completar su trabajo. De esta forma, el autor presenta la naturaleza como si fuera su propio enemigo y como si estuviera en contra del hombre. Algunos ejemplos de esto en la novela, son el caso de la muerte de Herminio, quien es aplastado por un árbol; la contaminación del agua, los zancudos, la fiebre amarilla, la malaria, el frío, los ríos que no son aptos para el transporte, la lluvia, la humedad, el calor, entre otros. Sin embargo, al hacer un análisis más a fondo con respecto a la naturaleza, se puede resaltar la problemática estructural que se vive en Limón en los años treinta: el paso del minifundio (pequeños agricultores) al latifundio (concesión territorial de la UFCO). Para este novelista es como si la naturaleza se vendiera al mejor postor y esto se aprecia cuando el campesino costarricense deja sus propias tierras para ir a trabajar en las plantaciones manejadas por inversiones extranjeras, aspecto que exalta el carácter nacionalista de esta novela.

Fallas utiliza una visión orgánica del capitalismo para analizar la totalidad de las partes del sistema costarricense y como resultado logra exhibir los efectos negativos del capitalismo. Principalmente, este escritor se apoya en la historia de 
la conquista española para explicar la idea de expropiación territorial y el establecimiento de tributos económicos que explotaba y sometía al pueblo indígena. El autor presenta a la United Fruit Company y al imperialismo yanqui como entes conquistadores que avanzan sobre los territorios costarricenses por medio de las concesiones territoriales que el Gobierno otorgaba a esa compañía. De esta forma, Fallas describe y exalta el nacionalismo como elemento para combatir el dominio y el control de las fuerzas extranjeras en Costa Rica:

La doma, el embrutecimiento del indio, la destrucción de la raza bravía, quedó para otros conquistadores mil veces menos valientes, pero infinitamente más crueles y rapaces de aquellos españoles, iy más arteros!: para los conquistadores imperialistas yanquis, secundados por criollos serviles. Y para otros tiempos: para los gloriosos tiempos de la República Democrática y Libérrima (Fallas, 2013: 74).

Con esta postura, el autor de Mamita Yunai establece una analogía entre la conquista española y el imperialismo estadounidense: así como el pueblo indígena perdió sus tierras y todos sus derechos frente a los españoles, el pueblo costarricense perderá sus territorios nacionales con la UFCO y con ellos todos los beneficios económicos que resultan de su explotación. Así, Fallas profetiza la esclavitud económica del pueblo costarricense ante las inversiones extranjeras y que al costarricense se le arrebatará la libertad de movilización dentro de su propio país. Además, el autor expone la relación entre las élites políticas y económicas (United Fruit Company y los políticos), las cuales gobiernan para sí mismas y no para el pueblo. Por último, critica el reconocimiento del inglés como idioma oficial utilizado en los modos de producción económica en la provincia de Limón, tema que se exhibe también en Mamita Yunai.

Adicionalmente, este escritor exalta la problemática de la expansión territorial de la UFCO hacia el Pacífico en busca de más beneficios económicos. La expropiación no solo se concentraba en el Caribe, sino que estaba esparciéndose desde la costa atlántica hacia la pacífica. Fallas denuncia tanto la pérdida de la propiedad territorial y las concesiones que el Gobierno costarricense hacía con la United Fruit Company, como la exoneración fiscal. Incluso, este novelista critica la carencia de soberanía del Gobierno costarricense sobre esas tierras, lo que permitió la creación de un sistema de administración por parte de esta compañía estadounidense en el suelo nacional. Por ejemplo, en la zona caribeña, la UFCO tenía el monopolio exclusivo del transporte (ferrocarril) y el acceso a los servicios públicos como: la educación, el hospital, las viviendas y el comisariato. Otros servicios como el agua y la electricidad eran destinados exclusivamente para la producción bananera y no para el uso cotidiano de los trabajadores. También, la United Fruit Company creó un sistema de pago en donde se cambiaban cupones de salarios por comida a los trabajadores. Fallas era consciente de la expansión económica, política e ideológica de la UFCO en Limón y se preocupaba 
especialmente por el empleo del idioma inglés en esta zona, pues promovía la segregación del pueblo costarricense para poder obtener mejores trabajos; dividiendo así a la población en dos bandos: los que hablaban español y los que hablaban inglés.

Precisamente, por medio del lenguaje hablado y las costumbres de los costarricenses, Fallas propone establecer un lazo entre blancos y negros para sentar las bases de un movimiento nacional antirracista y antiimperialista. Este novelista considera que se debe hacer un análisis de las clases sociales y sus intereses, especialmente en el caso de la United Fruit Company:

Ese grupo o clase de los explotadores, que nosotros llamamos BURGUESIA, es un grupo reducido. Sin embargo tenemos que declarado con vergüenza, ese pequeño grupo DOMINA, MANDA, GOBIERNA en el mundo entero. Es dueño de las máquinas, de los edificios, de las fábricas, en fin de todas las fuentes de riqueza y medios de producción. La burguesía es una clase explotadora que vive con el producto del trabajo ajeno (Fallas, 1935: 104).

De esta manera, Fallas recurre a un discurso pragmático y propagandístico para denunciar al imperialismo y defender a la clase obrera costarricense. Critica a la clase burguesa principalmente por tener el monopolio de los medios de producción y lo comenta cuando habla de los Estados Unidos y en especial de la United Fruit Company. Por tanto, se puede señalar que el lenguaje didáctico, pragmático y popular de Fallas está en función de atacar a la clase alta costarricense y a los inversionistas extranjeros:

TODO LO QUE BENEFICIA AL PUEBLO LABORIOSO PERJUDICA A LOS CAPITALISTAS; TODO LO QUE BENEFICIA A LOS CAPITALISTAS PERJUDICA AL PUEBLO TRABAJADOR. Por eso la clase Capitalista y la clase Trabajadora son MORTALMENTE ENEMIGAS: los trabajadores luchan porque los salarios suban; los capitalistas luchan porque los salarios bajen. Con ese fin, los trabajadores han forjado su propio Partido Comunista. Con él participan en las campañas electorales, se orientan y disciplinan en la lucha por la Conquista revolucionaria del poder. Mientras los trabajadores no cuenten con sus Sindicatos y con su Partido Comunista, no podrán tener esperanzas de mejorar su vida, y mucho menos la emancipación total (Fallas, 1935: 113-115. Mayúsculas pertenecen al original).

Estas ideas antiimperialistas contra la UFCO son también observadas en Mamita Yunai y permiten ver a las masas populares y oprimidas con la fuerza suficiente para atacar al opresor United Fruit Company por medio de la gran huelga de 1934. Aquí se observa que Fallas retrata de una forma realista la dominación imperialista y que emplea la palabra literaria con fines didácticos, así como describe la lucha del proletariado contra la burguesía costarricense.

Cabe señalar que al ser un país en vías de desarrollo, no contaba con recursos económicos propios, sino que necesitaba de la inversión extranjera para modernizarse 
e influir en el ámbito internacional; razón por la cual el Gobierno costarricense mostró una relativa debilidad política ante la United Fruit Company, ya que el Estado daba concesiones económicas a esta compañía para que invirtiera en el país, afectando entonces las condiciones laborales del obrero costarricense. A la larga, todo esto generó una serie de reformas sociales gracias a la clase obrera costarricense, la cual estaba representada a nivel político por medio del Partido Comunista (BOC) y específicamente como parte de una vanguardia política. La importancia recae en que estas ideas vanguardistas entendidas como políticas permitieron el desarrollo del sindicalismo en Costa Rica. Uno de los temas que Fallas más resalta en Mamita Yunai son las condiciones laborales que afectan a los trabajadores de las bananeras en Limón.

Esta novela permite exaltar el nacionalismo por medio de las condiciones laborales inhumanas que se vivían en las plantaciones bananeras. Así como las arduas horas de trabajo sin descanso y las condiciones climáticas debido al calor del clima tropical lluvioso con un alto nivel de humedad propio de la zona atlántica costarricense. También, destaca la pésima situación de higiene y los problemas de salud en la zona, entre ellos la abundancia de dengue, malaria y mosquitos, debido a las condiciones climáticas y a la falta de inversión del Gobierno para prevenir enfermedades. Es decir, se destaca la explotación de la UFCO y se victimiza al trabajador bananero. De esta manera, la novela exalta el sentir nacional y la necesidad de defender lo perdido y arrebatado por esa compañía. Además, Fallas documenta elementos verídicos en la novela como la enfermedad del Panamá que fue un hongo que los bananos desarrollaron y, en consecuencia, se fumigaron los bananales con químicos sin ofrecerles ninguna protección a los empleados ni a quienes vivían en la zona:

Badilla padecía de un catarro crónico, muy común en las peonadas, y vivía con la obsesión de que le estaba pudriendo la cabeza. Con mucha frecuencia padecía también de un fuerte dolor de cintura, que el pobre resistía crujiéndose los dientes. A ratos imploraba a Dios (Fallas, 2013: 146).

Sin embargo, lo más difícil en la zona bananera era utilizar los servicios médicos y los hospitales. Aunque los empleados debían pagar por estos servicios, los trabajadores no tenían derecho a enfermarse y eran víctimas de maltrato médico, discriminación y negligencia por parte del patrono. Tal es el caso del personaje Herminio que no pudo trasladar a su esposa al hospital porque el patrono mencionó que las mulas y los carros eran solo para la producción de banano y no como medio de transporte para los enfermos:

La historia de Herminio era triste y muy negra. No quiso, me dijo, volver a su presidio. Cansado y para aliviar sus penas, buscó una mujer y se fue con ella al corazón de una finca. Allí trabajaron y sufrieron juntos la inclemencia del clima, los ultrajes del gringo y la explotación del Comisariato. Y cuando la Compañía ordenaba botar el banano cortado, para evitar la baja del 
precio en el mercado extranjero, perdian su trabajo y se mordian las uñas. Así, hasta la enfermedad de su mujer, que se quedó de abandono en la finca, sin poderla sacar acurarse por falta de dinero y por falta de un carro para llegar a la linea del ferrocarril. El gringo le dijo que las mulas y los carros eran para acarrear el banano y no para jalar enfermos (Fallas, 2013: 224).

Con este ejemplo, el autor trata de sensibilizar a la clase obrera marginada sobre la explotación de la UFCO y en especial al sector más indefenso: las mujeres. En palabras campesinas, este novelista expresa que los intereses económicos de la compañía están por encima de los trabajadores y los valores familiares costarricenses.

Fallas también señala que el "doctor" de la bananera era un fraude, y lo describe como un ignorante porque de medicina sabía tanto el médico como los peones de astronomía. Además, el autor hace visible la problemática y la división de las clases sociales en Costa Rica por medio de las condiciones laborales y la falta de atención médica para los empleados de la UFCO:

Subiamos agachados por el dolor de cintura, emparejábamos y volvíamos al hueco. Al poco rato ya estábamos desnudos de la cintura para arriba y el sudor corría a chorros cegando los ojos, mojando los pantalones, resbalando por los brazos. Y así horas y horas hasta sentir náuseas y temblor en las piernas y un martillero horrible en la cabeza. Un calor sofocante y pesado iba envolviendo poco a poco la montaña (Fallas, 2013: 134).

Fallas describe con palabras coloquiales y sinceras la cruda realidad del trabajador costarricense. De esta manera, Fallas permite acercarse a la clase trabajadora e identificarse con las condiciones inhumanas que vivían los jornaleros en el cultivo del banano. Asimismo, Fallas demuestra las pésimas condiciones que los hospitales ofrecían a los jornaleros a pesar de que estos debían pagar por esos servicios:

-Hermano-le dije-, al día siguiente de aquello, me sacaron también a Limón con una fiebre espantosa. Yo me opuse a que me llevaran al Hospital de la Compañí. No quería morirme com'un perro allí, como se mueren tantos infelices. ¡Hospital llaman a ese matadero! Pensar que todas las quincenas hay qui'aflojar la plata pa'ese famoso hospital. ¡Cuántos miles de dólares no s'echará a la bolsa la Compañía! (Fallas, 2013: 219).

En su narrativa, Fallas busca crear una identificación de la realidad costarricense y exaltar las condiciones inhumanas con la finalidad de que el trabajador costarricense identifique a la UFCO como el enemigo. Es decir, Fallas utiliza un discurso social antiimperialista, para así crear una unión entre los trabajadores sin distinción de raza para luchar contra el capitalismo y crear una revolución pacífica obrera que permitiera modificar la problemática social costarricense. Por ende, las ideas imperialistas del Partido Comunista y la ideología del Comunismo a la Tica presentadas en 
la novela Mamita Yunai permitieron exaltar la identidad nacional del costarricense y unificar al trabajador blanco y negro. Su principal objetivo era defender la patria contra las inversiones extranjeras, las cuales se adueñaban del territorio nacional y esclavizaban a los obreros. Por esta razón, la novela Mamita Yunai incentiva a los trabajadores en la lucha antiimperialista al convertirlos en guerreros de la Patria y héroes de una revolución sindicalista.

\section{Visión fragmentada de las razas costarricenses}

Aunque Fallas unifica los odios de los trabajadores blancos y negros contra la UFCO, también fragmenta su visión sobre las razas en Costa Rica cuando presenta la problemática de los indígenas: "Poco a poco, la indiada lo fue perdiendo todo, hasta quedar en lo que está hoy: el ochenta por ciento no tiene absolutamente nada. Arañan la montaña para obtener un puñado de café, otro de maíz y unos cuantos bananos; luego se doblan bajo el peso. A peso de oro: el azúcar es oro en polvo para el indio y la sal también" (Fallas, 2013: 77). Con esta postura, el autor caracteriza a los indígenas por medio de parámetros que no se asocian con el capitalismo, pues señala la pérdida de la propiedad privada y critica la falta de un plan económico que les permita la producción de bienes. La opción del verbo "arañan" se asocia con la lucha por la producción de un cultivo en condiciones territoriales no aptas para la cosecha y no utiliza otro verbo como "trabajar" que se relaciona más con la remuneración económica.

Durante la novela, el autor no menciona el uso de la moneda costarricense, sino que describe el intercambio de bienes, pues los indios no creían en el dinero. Con esto Fallas se da cuenta de que los indios, al no estar interesados en el capital, no le ayudarían en la lucha ideológica contra el capitalismo y por eso trabajó por la unión de los blancos y los negros, y criticó a la población india: “Talamanca es una región poblada de indios, en su mayoría analfabetos, casi no hablan español y hacen una vida primitiva y miserable. Viven agrupados en rancheríos cerca de las márgenes de los diferentes y caudalosos ríos o en el corazón de la montaña" (Fallas, 2013: 7). Sin embargo, en ningún momento exalta las características positivas del indígena en la sociedad como sí lo hace con los afrocaribeños, sino que más bien critica la falta de adaptación de los pueblos indígenas a la sociedad, al sistema educativo y a los modos de producción para el desarrollo económico del país.

En la trama de la novela, el autor utiliza juicios de valor que permiten categorizar y ver las diferencias de trato entre las razas negra e india, lo cual fragmenta su visión. Fallas establece una discrepancia entre las razas: blanca, negra e indígena. Esta separación permite introducir creencias de la forma de vida de los indígenas de una forma negativa en la narrativa de la novela, permitiendo así describir diferencias culturales basadas en la raza, las tradiciones culturales como el lenguaje y la forma de 
vida; así como su origen geográfico. Tal es el caso de la segregación social que se ve en la novela: "Yo era el único blanco que viajaba en el carro y, como no entiendo inglés, no podía ni siquiera entretenerme orejeando lo que animadamente conversaban un grupo de negritas sentadas en sus cajones" (Fallas, 2013: 9). Este comentario permite apreciar una segregación no solo por el color de piel cuando dice que es "el único blanco", sino que se observa también la discriminación a partir del idioma inglés y el español, una barrera que imposibilita la comunicación entre las personas.

Fallas continúa categorizando las razas y describe a la negra no como hombres, sino como demonios negros y musculosos: "los hombres, que más que hombres parecían demonios negros y musculosos brillando bajo el sol, sentados en las orillas con los pies colgando, o de pie, apoyándose los unos contra los otros" (Fallas, 2013: 8). Con esta descripción física pareciera que quiere exponer a los negros como personas musculosas y fornidas que se apoyan los unos contra los otros bajo el sol. La palabra "demonio" en este contexto tiene una connotación negativa vinculada con lo espiritual, como si fuera una persona oculta, oscura y misteriosa.

Bernal Morera Brenes y Ramiro Barrantes analizan la realidad vivida por poblaciones blancas y negras en esa época. Por ejemplo:

Otro planteamiento histórico proponiendo [propone] que Costa Rica es uno de los pocos países latinoamericanos donde predomina la "raza blanca".. Casi todos los costarricenses son descendientes de europeos (principalmente de España) a diferencia de los nativos de otros países en América Central (ICT 1990)... describiendo la población como 97\% caucasoide (Morera Brenes y Ramiro Barrantes, 1997: 49).

La historia costarricense muestra rechazo contra la raza negra. A pesar de ser solo una pequeña parte de la población costarricense, los negros ganaban económicamente más que cualquier hombre de raza blanca y esto generaba disconformidad y resentimiento en el ciudadano blanco. De ahí que este escritor se ampara en la expansión territorial de la UFCO y la explotación laboral para unificar a los trabajadores blancos y los negros con el fin de iniciar su batalla contra el imperialismo yanqui, y utiliza la obra Mamita Yunai como una burla hacia los Estados Unidos.

Si bien es cierto, Mamita Yunai expone las condiciones socioeconómicas de los trabajadores, y presenta una descripción contradictoria y distorsionada de las razas y de las mujeres. En efecto, ambos son excluidos de las ventajas de la unificación del proletariado contra el capitalismo, lo que produce un fraccionamiento de la visión de Fallas. Esta situación provoca un vacío en la novela, el cual no encuentra una solución a nivel social para los indios y las mujeres. Esto se debe a que Fallas cree que estos no están vinculados con los medios de producción y, por ende, quedan fuera de la defensa antirracista. De esta forma, el autor exalta el antirracismo únicamente en estas dos razas (blanca y negra), debido a que comparten la explotación laboral de la UFCO. 


\section{Visión fragmentada de Fallas sobre el racismo}

Como fue señalado anteriormente, Mamita Yunai exalta la unificación entre los costarricenses blancos y los afrocaribeños, y expone una postura antirracista entre el blanco y el negro. Pues presenta a estos últimos como personas amables que le ofrecen comida, le ayudan en su dirigencia y en quienes confía para dormir junto a ellos. Sin embargo, al estudiar esta novela y hacer un entrelazado se puede observar una discriminación entre negros e indios, pero Fallas también los trata con cariño, pues los llama "negritos" y "negritas":

Se hacia tarde y una de las negritas de mi carro sacó, de debajo de unos chunches una palangana tapada con hojas de banano en la que guardaba el sontin: arroz con bacalao, esponjados pedazos de yuca y grandes pedazos de ñame... saciado el apetito convidaron a los muchachos que iban sentados en la parte delantera del carro y al volverse uno de ellos nos reconocimos mutuamente (Fallas, 2013: 9-10).

Desde sus primeros encuentros, Fallas señala de forma positiva a los negros costarricenses y muestra su confianza y su admiración por trabajar y mantenerse unidos para enfrentar la discriminación en el país. Pero, al mismo tiempo habla con desprecio hacia los indios y pareciera utilizar juicios de valor y etiquetas con los indios como personas que engendran desconfianza. Utiliza además estas frases que aparentan describir de una forma negativa al indio como: tonto por negocio, con un acento desconfiado y hostil, de risa estúpida, con miradas de reojo, los indios son más vivos de lo que parecen. Estas palabras ayudan a formar una visión negativa hacia la raza indígena. La desconfianza entre el autor y los personajes es obvia e incita al lector a ver a los indígenas de una forma subjetiva: "Se trataba de dos indios jóvenes... Uno era alto y fornido... El otro, bajito y esmirriado, con una carilla afilada que bien podía ser de un ingenuo o de un taimado, me dio la impresión de un zamarro metido a tonto por negocio" (Fallas, 2013: 20). Más aún, este novelista expresa abiertamente su desconfianza contra los indios y admite engañarlos para sentirse protegido en presencia de los indios:

El indio se detuvo medros y con ojos asustados examinó a vegetación que nos rodeaba. Era la oportunidad que yo buscaba para engañarlo e infundirle respeto. -- ¿Tenés miedo del tigre? No tengás miedo, yo llevo revólver -le dije, mientras me tocaba el foco que llevaba por dentro de la camisa. Desde entonces continuó el camino cabizbajo y no se le ocurrió volver a gritar (Fallas, 2013: 25).

Este pasaje puede asociarse con la historia de la colonización y la derrota de la civilización indígena cuando Fallas demuestra la superioridad de la raza blanca sobre la indígena, en especial al señalar el uso de armas de fuego. Con esto, 
el indio permaneció cabizbajo con la mirada en el suelo en señal de derrota psicológica y sometimiento.

Además, al analizar el tema de la comida entre la raza india y negra se observa directamente el desprecio de Fallas al no querer aceptar la comida de los indios. A diferencia de lo que piensa de la comida de los hombres de raza negra, la cual describe de una forma exótica y apetecible, la comida india es presentada con desprecio. Así, decide volver a engañar a los indios y hacerse el dormido antes de ingerir el alimento indígena: "Me acosté hasta con el sombrero puesto y a los pocos segundos estaba habiendo que roncaba sobre las bolsas, con el objeto de que no me ofrecieran de comer... Dos perros sarnosos me pasaron por encima y terminaron por acomodarse entre mis piernas" (Fallas, 2013: 35). El comportamiento del narrador indica un respeto por la cultura negra y una falta de consideración a la cultura indígena.

Al estudiar detenidamente la actitud de Fallas hacia los indios y los negros, se nota su visión fragmentada hacia las distintas razas, cómo crea una opinión amparada en los juicios de valor, deja su objetividad como escritor testigo, y produce una contradicción al exponer que la inteligencia depende del color de piel: “Esos no eran indios puros. El pelo crespo o sedoso y la piel más quemada o casi blanca denunciaban el cruce con el negro o con el castellano. Debían de ser los más listos" (Fallas, 2013: 49). De acuerdo con esta posición, el novelista exhibe su opinión personal y clasifica a los mestizos como personas más inteligentes porque al mezclarse con otras razas (negra y blanca) eran más hábiles que los indios "puros". Con esos argumentos, se puede apreciar contradicciones ideológicas con respecto al racismo. El narrador expone directamente un apoyo a la raza africana pero un desprecio a la indígena costarricense. La Real Academia Española (RAE) define al racismo como una exacerbación del sentido racial de un grupo étnico, en especial cuando convive con otro u otros. Y esto es específicamente lo que hace Carlos Luis Fallas en Mamita Yunai donde escribe su propia experiencia personal y concretamente por el hecho de haber convivido con negros e indios durante su travesía para encontrar la mesa de elecciones.

Si bien es cierto, Fallas aboga por una igualdad universal, también establece una postura que no toma en cuenta los derechos de los indígenas. Entonces, deja de lado su objetividad e introduce su propia visión al incorporar elementos subjetivos en la obra Mamita Yunai. Este autor establece una contradicción moral en cuanto al racismo y acaba favoreciendo a los negros. Cabe señalar que en Costa Rica los indios y los negros vivían separados de los blancos. Fallas logra visualizar que las luchas sociales se van a forjar entre los blancos y negros, y no entre indios y blancos. Fallas enfoca su ideología por medio de una lucha social entre los trabajadores bananeros. Aquellos que buscaban obtener una mejor remuneración económica (blancos y negros). Y para lograr darle fuerza a esa lucha unifica a la raza blanca con la negra. Dejando a un lado la lucha social y económica de los indígenas en la novela. Esto permite ver una realidad contradictoria que no calza con el punto de vista de los historiadores y que posteriormente separa a 
la población costarricense en indios y blancos, pero une a blancos y negros. Entonces, también se debe reconocer que en Mamita Yunai, el autor se contradice especialmente porque produce una fragmentación de la totalidad sistemática en el caso del racismo hacia el indio costarricense.

Para ejemplificar esta fractura, se recurre a la misma novela donde el autor califica a los indios de una manera que expresa segregación y desprecio al usar frases como "esas gentes" y "estos tipos" para hacer referencia a los indios: “Qué diablos beberían esas gentes que los obliga a orinar tanto?" (Fallas, 2013: 35) y “- ¡Nasigua! ¡Chiquirina! - y la indiada reía burlándose de mí. ¿Qué diablos estarían diciendo estos tipos? Sospechando que estuvieran azuzando contra mí a la indiada" (Fallas, 2013: 51). En particular, el ejemplo de ¡Nasigua! ¡Chiquirina! es repetido muchas veces en la novela. La reiteración de estas palabras tiene una repercusión directa en el lector, ya que Fallas repite la forma en la cual los indios se burlaban de él con el objetivo de establecer una victimización en la novela a través de la burla. Así lo menciona Fallas: “-¡Nasigua! ¡Chiquirina!" - murmuraban los indios entre risas y volvían a la carga. Los miembros de la Junta reían entre dientes... (Fallas, 2013: 52), “-iNasigua, nasigua! ¡Chiquirina!” (Fallas, 2013: 57), “-¿Sabe, Sibajita? Pues, nasigua quiere decir 'enemigo', y chiquirina... 'Perru enfermo' (Fallas, 2013: 71). Como se puede observar, en la novela hay una representación que desacredita la amistad del indígena con el hombre de raza blanca.

Precisamente, el racismo en Costa Rica es un tema de gran importancia y queda representado en la novela debido a la estratificación de las clases sociales y económicas, producto de la clasificación del trabajo de acuerdo con la raza y el idioma del trabajador. La historia del racismo se inicia en Costa Rica en los tiempos coloniales. Este país mantuvo una posición discriminatoria con cualquier raza que no fuera blanca y europea:

En 1862 se constituye en Costa Rica un territorio nacional para la defensa de las invasiones extranjeras, se crea un héroe nacional pero más importante se establece la idea de homogeneidad "racial" y para ello se cuenta con la creación de leyes que favorecian los intereses de la herencia Europea la cual formó la identidad nacional del país. (Harpelle, 2001: 8).

Más aún, la política costarricense muestra una legislación racista y discriminatoria con el uso de las llamadas Leyes de Bases y Colonización (Harpelle, 2001: 12). El Gobierno de Costa Rica dictó políticas racistas que impidieron a los inmigrantes africanos desplazarse libremente en el territorio. Tampoco estaba permitido el matrimonio interracial porque era considerado ilegal y antimoral por la Iglesia católica (Harpelle, 2001: 21). Por otra parte, el gobierno costarricense había tomado medidas legales en contra del mestizaje entre la población blanca y de la raza negra. Como describe Harpelle, el Gobierno costarricense quería prohibir los matrimonios interraciales para evitar lo que estaba ocurriendo en Panamá, donde la población se convertía en una 
nación predominante negra (Harpelle, 2001: 84-85). Esta posición racista también se puede encontrar en el artículo 5 del Archivo Nacional, sección histórica número 2507 del año 1904, en el cual se prohibía a la gente de color trabajar fuera de las plantaciones de banano (Seligson, 1980).

Todo esto es relevante al examinar la novela de Fallas, pues la separación y la segregación racial queda plasmada en Mamita Yunai donde se describe la frustración de los afrocaribeños al no tener trabajo y verse en la obligación de emigrar a Panamá a buscar trabajo en la construcción del Canal:

No hay trabajo, ni podemos cultivar en la tierra, ni nos dejan ganarnos la vida en el Pacífico... ¿nos tenemos que morir de hambre, entonces? No somos cuatro, somos miles de negros costarricenses que tampoco podemos convertirnos en salteadores. Por eso es que tenemos que irnos pa' Panamá (Fallas, 2013: 10-11).

El autor de la novela también describe la realidad costarricense a través de sus historias y sus personajes. El historiador costarricense Iván Molina resalta el racismo y xenofobia en esa época. Según este autor, el racismo era especialmente hacia los negros, chinos, nicaragüenses y judíos. No obstante, la mayoría de inmigrantes africanos provenía de Jamaica y llegaba a Costa Rica para la construcción del ferrocarril en el Atlántico. Esto permitió la formación de una minoría étnica en Costa Rica. Al mismo tiempo, Lara Putnam, quien presenta la realidad costarricense en The Company They Kept: Migrants and the Politics of Gender in Caribbean Costa Rica, también justifica este argumento. En efecto, la discriminación se presentó, además, con la inmigración de jamaiquinos en el caribe costarricense, lo cual permitió la movilización de empresas americanas que buscaban mano de obra barata y trabajadores con dominio del idioma inglés. Esto llevó a que la United Fruit Company se instalará en el Caribe de Costa Rica y con ello se origina la producción y exportación del banano.

Pese a ese avance en los medios de transporte, se dio paralelamente la discriminación racial y la segmentación económica, aspectos que se aprecian en Mamita Yunai: "La Compañía, para vivir a salvo de posibles rebeliones serias, azuzaba el odio de blancos contra negros y de negros contra blancos" (Fallas, 2013: 234). Se exacerba la discriminación entre el costarricense de piel blanca y el de piel negra. En efecto, esta novela describe la jerarquización racial basada en el color de la piel por parte de aquellos que asimilan la idea del blanqueamiento:

Dedicábamos los domingos a lavarla ropa. Desnudos los tres en el río, sentados cada uno en su piedra, comenzábamos la aburrida tarea. Calero, posiblemente con la esperanza de lograr blanquear así su pellejo achocolatado, se enjabonaba en su piedra y en esas fachas pasaba horas, dándole a los chuicas. Al principio parecía una montaña de espuma con ojos; pero poco a poco, los rayos ardientes del sol le iban secando el jabón, que se le cortaba entonces sobre la piel (Fallas, 2013: 186). 
En esta cita Fallas utiliza estos elementos cotidianos para destacar la discriminación racial de la época. Esta purificación al cuerpo, en la novela de Fallas, refleja las políticas racistas de blanqueamiento en Costa Rica: "Este sistema fue inspirado y defendido por la Iglesia Católica por sus nociones sobre la 'limpieza de sangre' y 'cristianismo nuevo'"' (Morera Brenes y Ramiro Barrantes, 1997: 46). Así, el autor describe las ideas de limpieza y purificación racial que tanto en la novela como en la realidad se ven con ejemplos, entre ellos el bañarse con jabón por varias horas, lo que da a entender que la población afrocaribeña era discriminada socialmente y buscaba volverse más blanca, más "pura, más limpia, y libre de pecado".

Además, en Mamita Yunai se observa que los afectados son directamente los afrocaribeños no solo por el prejuicio social, sino también por las condiciones económicas y sociales en las que vivían en Costa Rica. Esta realidad se puede complementar con la posición de Harpelle, quien documenta que la decadencia de la población de herencia africana en Costa Rica se debe a las pésimas condiciones laborales e higiénicas que traían, entre otros aspectos, enfermedades y malnutrición. Esta posición es bien reflejada en Mamita Yunai:

Cabo Pancho mandaba al menor de los Jerez a traer agua para todos. Y llegaba el agua del suampo, tibia y espesa como linaza, turbia por el lodo y los residuos de palos podridos... Calero siempre se quedaba de último para poder meter la cabeza dentro del tarro y beber grandes sorbos imitando las mulas." ¡Llenate la panza de amebas y anquilostomas! -le dije yo una vez. ¿Qué voy a beber entonces? (Fallas, 2013: 135).

Calero se enfermó de pronto. Un dolor agudo le destrozaba el estómago. Bramaba revolcándose en el piso, mordiendo las tablas; se levantaba haciendo muecas de angustia, escupiendo una baba negra de tierra y corría hacia el monte. Nosotros oíamos sus dolorosos pujidos, sin poder hacer nada por él. Los sitios que usaba, quedaban marcados por cuajones de sangre verdosa y hedionda (Fallas, 2013: 205-206).

- No hermano - le dije - son las amebas y los bichos que te has tragao con el agua del suampo, los que hora t'están mordiendo las tripas (Fallas, 2013: 206).

Con estos ejemplos, este novelista quiere resaltar la terrible realidad que enfrentaban los afrocaribeños en Costa Rica y las condiciones inhumanas de trabajo, en especial y al comparar directamente a los negros con los animales de trabajo, como las mulas, ya que tenían el mismo trato (ambos tomaban agua en tarros). El caso particular de Calero se destaca por su muerte tras tomar agua contaminada, realidad que Harpelle expone también. Además, la terrible descripción física de la muerte de Calero 
permite sensibilizar al lector sobre la problemática costarricense y hacerlo tomar conciencia del valor de la vida humana y la igualdad racial.

No obstante, durante la novela, Fallas amplía su visión y a pesar de mostrar diferencias entre los hombres por el color de su piel, empieza a establecer una unificación entre las razas: "No podíamos, pues, convidar a nadie fuera de nuestro grupo. Solo al negro de Clinton le escondíamos uno, porque él siempre nos convidaba cuando mataba tepezcuincles" (Fallas, 2013: 140). La convivencia y las condiciones de trabajo entre estos personajes de raza blanca y negra permitieron reducir las diferencias raciales.

Ante todas estas injusticias laborales, el comunismo en Costa Rica desarrolló una política social que promovía la igualdad racial y una división económica más equitativa. El Partido Comunista (BOC) utilizó la igualdad de derechos para fundamentar su ideología unificadora:

Nosotros, por imperativo de doctrina, repudiamos el odio a las razas. Nuestra doctrina es progresista, empuja a la humanidad hacia adelante, le abre las perspectivas de superación... Y lo hay más primitivo y absurdo en el hombre son los odios a otros hombres, por el hecho de que sea diferente en su formación racial (Molina, 2008: 163).

No sorprende entonces ver que el único actor que estaba en contra de estas leyes de discriminación racial fuera el Partido Comunista (Harpelle, 2001). Esta política antirracista queda manifestada en Mamita Yunai cuando Fallas establece una conexión entre el racismo y la explotación de la United Fruit Company. Este novelista expone la cruda realidad del negro costarricense y en su historia se observa la injusticia social y la desigualdad humana que vivía día tras día. Presenta al negro como un esclavo, dominado, maltratado, perseguido, desamparado por las leyes costarricenses y los derechos civiles. En su narrativa, Fallas busca crear una identificación de la realidad costarricense y exaltar las condiciones inhumanas con el objetivo de que el trabajador costarricense identifique a la UFCO como el enemigo y con eso crear una unión entre los trabajadores sin importar su raza para luchar contra el capitalismo y crear una revolución pacífica obrera que permitiera modificar la problemática social costarricense.

\section{Conclusión}

Mamita Yunai logra vincularse con el vanguardismo político por medio del realismo social y de la ideología antiimperialista del Partido Comunista. Esta novela permite identificar a los trabajadores como héroes de la revolución obrera, luchadores contra la opresión laboral y contra el monopolio extranjero. Aunque Costa Rica a nivel latinoamericano presenta una debilidad en la vanguardia artística, este país expone una fuerte vanguardia política debido a su "comunismo a lo tico" y sus repercusiones políticas y literarias expresadas en Mamita Yunai. 


\section{Bibliografía}

Acuña, Víctor Hugo. La Huelga Bananera de 1934. San José: CENAP y CEPAS, 1984.

. "Mamita Yunai: Un cuarto de siglo después". Comunicación 18 (2009): 39-46.

Aguilar, Marielos. "Carlos Luis Fallas, Su Época y sus luchas". Anuario de Estudios Centroamericanos (1984): 163-164.

Bell, John Patrick. Crisis in Costa Rica: The 1948 Revolution. Austin: University of Texas Press, 1971.

Biesanz, John y Hiltunen Biesanz, Mavis. Costa Rican Life. New York: Columbia University Press, 1944.

Booth, John. A. Costa Rica: Quest for Democracy. Colorado: Westview Press, 1998.

Botey, Ana María y Cisneros, Rodolfo. La Crisis de 1929 y la Fundación del Partido Comunista de Costa Rica. San José: Editorial Costa Rica, 1984.

Bourgois, Phillippe. Ethnicity at Work: Divided Labor on a Central American Banana Plantation. Baltimore: The Johns Hopkins University Press, 1989.

Castro Robles, Guillermo. Análisis Estilístico de Mamita Yunai. San José: Universidad de Costa Rica, 1975.

Cerdas Mora, Jaime. Memorias Jaime Cerdas Mora La Otra Vanguardia. San José, Costa Rica: Editorial Universidad Estatal a Distancia, 1993.

Ching, Eric. “El Partido Comunista de Costa Rica 1941-1935: Los Documentos del Archivo Ruso del Comintern". Revista de Historia / Escuela de Historia, Universidad Nacional, Centro de investigaciones Históricas, Universidad de Costa Rica 1.1 (1998): 01-244.

Collier, Michael W. Political Corruption in the Caribbean Basin: Constructing a Theory to Combat Corruption. New York, New York: Routledge Taylor and Francis Group, LLC, 2005.

Comisión Política del Partido Vanguardia Popular. "Manuel Mora cumple 70 años: Toda una vida a la lucha por el bienestar popular de la democracia y el socialismo". Trabajo (1979): 1-56.

. "Revista del Comité Central del Partido Vanguardista Popular". Trabajo NoviembreDiciembre (1978): 3-45.

Contreras, Gerardo. Vivencias del Partido Vanguardia Popular. San José: Ediciones Perro Azul, 2008.

. Algunos Antecedentes para Comprender la Política de Alianzas del Partido Comunista de Costa Rica en la Década de los años cuarenta. San José: Porvenir, 1988.

Cuvardic García, Dorde. "Idilio y Elegía en la Narrativa de la Generación Nacionalista". Revista de Artes y Letras de la Universidad de Costa Rica XXX1. (2007): 207-214.

Díaz, David. Prof. de Historia de la Universidad de Costa Rica. Entrevista personal. Julio de 2014.

Dobles Oropeza, Ignacio. Militantes: La Vivencia de lo Político en la Segunda Ola del Marxismo en Costa Rica. San José: Editorial de la Universidad de Costa Rica, 2005.

Fallas Sibaja, Carlos Luis. De mi vida Tomo I y II 1909-1966. Heredia: Editorial Universidad Nacional, 2013.

. El Peligro de la Dictadura: Las Elecciones y la Organización Sindical. San José: Imprenta Tormo, 1935.

Fallas, Carlos Luis. Mamita Yunai. San José: Editorial Costa Rica, 2013.

Harpelle, Ronald N. The West Indians of Costa Rica. Montreal: McGill-Queen's University Press, 2001.

Hernández, Juanita. “El Comunismo en Costa Rica”. Tesis. Universidad de Costa Rica, 1942.

Hobsbawm, Eric. How to change the word: Tales of Marx and Marxism. New Haven: Yale University Press, 2011. 
Hugo, Verani J. Las Vanguardias Literarias en Hispanoamérica. México, D.F: Fondo de Cultura Económica, S.A., 1986.

Jones, Chester Lloyd. Costa Rica and Civilization in the Caribbean. Madison: University of Wisconsin, 1935.

Jones León, Sonia. "Restructuración de Mamita Yunai a partir de la manipulación textual". Kañina, Rev. Artes y Letras XXXIV (2010): 27-35.

Leandro Zúñiga, Vilma y Dobles Oropeza, Ignacio. “El Marxismo Costarricense en Perspectiva y Retrospectiva". Revista de Ciencias Sociales (2003): 189-250.

Lehoucq, Fabrice E. y Molina, Iván. Stuffing the Ballot Box: Fraud Electoral Reform, and Democratization in Costa Rica. New York: Cambridge University Press, 2002.

Leitch, Vincent B. The Norton Anthology Theory and Criticism. New York: W.W. Norton \& Company, 2001.

Liss, Sheldon B. Radical Thought in Central America. Colorado: Westview Press, Inc., 1991.

Liss, Sheldon y Liss, Peggy. Man, State and Society in Latin American History. New York: praeger Publishers, 1972.

Mackenbach, Werner. "Banana Novel Revisited: Mamita Yunai o los Límites de la construcción de la Nación desde abajo". Revista de Artes y Letras de la Universidad de Costa Rica XXX (2006): 129-138.

Merino del Río, José. Manuel Mora y la democracia costarricense: viaje al interior del Partido Comunista. Heredia: Editorial Fundación UNA, 1996.

Mesa-Lago, Carmelo. Market, Socialist, and Mixed Economies. Baltimore: The John Hopkins University Press, 2000.

Molina, Iván. Prof. de Historia de la Universidad de Costa Rica. Entrevista personal. Julio de 2014. . (s. f.). Iván Molina Jiménez. Historia-ciencia ficción. <http://ivanmolinajimenez.wordpress.com/>.

. “Comunistas y anuncios comerciales. La experiencia de Costa Rica en la década de 1940". Memoria Social (2013): 218-234.

"Publicaciones y Postergaciones Carlos Luis Fallas y el Partido Comunista de Costa Rica (1940-1954)". Cuadernos de Intercambio (2012): 127-145.

. “Carlos Luis Fallas: Difusión, comercialización y estudio de sus obras: Una contribución documental". Revista Ciencias Sociales (2011): 179-205.

. “El Partido Comunista de Costa Rica y la importación y comercialización de materiales impresos (1931-1948)". Historia y Política (2010): 239-264.

. "Communists and Advertising in Costa Rica of the Trabajo Newspaper". Escuela de Historia de la Universidad de Costa Rica (2009): 61-87.

. "Afrocostarricense y comunista Harold Nichols y su actividad Política en Costa Rica". Latinoamérica. Revista de Estudios Latinoamericanos (2008): 141-168.

. "La influencia del marxismo en la historiografía costarricense". A Contra Corriente (2008): 220-236.

. “Orígenes de la reforma social en Costa Rica: Iglesia Católica y comunistas en la década de 1940". Iconos. Revista de Ciencias Sociales (2006): 137-145.

. “Orígenes de la Reforma Social en Costa Rica: Iglesia Católica y comunistas en la década de 1940". Iconos. Revista de Ciencias Sociales (2006): 137-145.

. “Catolicismo y comunismo en Costa Rica 1931-1940". Desacatos número 22 (2005): 157-172. 
- "Prensa, propaganda electoral y comunismo en Costa Rica durante la década de 1930 y 1940". Escuela de Historia de la Universidad de Costa Rica (2005): 407-423.

"Un pasado comunista por recuperar: Carmen Lyra y Carlos Luis Fallas en la década de 1930". Ensayos políticos. San José: Editorial de la Universidad de Costa Rica, 2000.

. “¿De vuelta a los ocho años? A propósito de la guerra de Figueres de Guillermo Villegas Hoffmeister". Revista de Historia 41 (2000): 192-198.

. "Fraude Electoral y cultura popular en Costa Rica (1902-1948)". Escuela de Historia y Geografía (s. f.): 1-29.

Molina Jiménez, Iván. Los Pasados de las Memoria: El Origen de la Reforma Social en Costa Rica (1938-1943). Heredia, Costa Rica: Editorial Universidad Nacional, 2008.

. Anticomunismo Reformista: Competencia Electoral y Cuestión Social en Costa Rica 19311948. San José, Costa Rica: Editorial Costa Rica, 2007.

. Ensayos Políticos Carmen Lyra y Carlos Luis Fallas. San José: Editorial de la Universidad de Costa Rica, 1999.

Monge, Carlos Francisco. El Vanguardismo literario en Costa Rica. Heredia, Costa Rica: Editorial Universidad Nacional EUNA, 1951.

Montero Berry, Gonzalo. "Huelga General en la Zona Atlántica". La Voz Sindical 12 de agosto de 1934: 7.

Mora, Eduardo. Autocrítica y Perspectiva Revolucionaria en la Construcción del Partido. San José: Editorial Costa Rica, 1984.

Morera Brenes, Bernal y Barrantes, Ramiro. "Genes e Historia: El mestizaje en Costa Rica". Revista de Historia / Escuela de Historia, Universidad Nacional, Centro de investigaciones Históricas, Universidad de Costa Rica. 1.1 (1997): 43-64.

Ochoa Zavaleta, Eugenia. Las Exposiciones de Artes Plásticas en Costa Rica (1928-1937). San José: Editorial Universidad de Costa Rica, 2004. . Organizadora, Directora del CIICLA, Universidad de Costa Rica. Entrevista personal. Julio de 2014.

Palmer, Steven y Molina, Iván. The Costa Rica Reader: History, Culture, Politics (The Latin America Readers). Durham: Duke University Press, 2004.

Putnam, Laura. The Company they kept: Migrants and the Politics of Gender in Caribbean Costa Rica. Chapel Hill: University of North Carolina Press, 2000.

Samper, Mario. Generations of Settlers: Rural Households and Markets on the Costa Rican Frontier, 1850-1935. Westview Press: 1990.

Seligson, Mitchell A. Peasant of Costa Rica and development of Agrarian Capitalism. Madison: University of Wisconsin Press, 1980.

Sibaja Barrantes, Emel. “Características Generales del Enclave en Costa Rica 1880-1933”. Nuevo Humanismo (1984): 110-122.

Solís, Manuel. Prof. de Sociología de la Universidad de Costa Rica. Entrevista personal. Julio de 2014.

Solís Avendaño, Manuel A. Memoria Descartada y Sufrimiento Invisibilizado: La violencia política de los años cuarenta vista desde el Hospital Psiquiátrico. San José: Editorial UCR, 2013.

Verani, Hugo J. Las Vanguardias Literarias en Hispanoamérica Manifiestos, proclamas y otros escritos. México: Fondo de Cultura Económica, 1990. 
Vanessa Díaz López, conocida como Vanessa Pietras posee una doble nacionalidad: costarricense y estadounidense. Dentro de los títulos académicos se encuentran: bachiller, licenciada y máster en Relaciones Internacionales de la Universidad Nacional de Costa Rica (UNA) y máster en Lenguas Extranjeras y Literatura de la Universidad de North Carolina State, Estados Unidos. Actualmente, cursa en el programa de Educación y es asistente en el programa de Maestrías en la Facultad de Lenguas Extranjeras, ambas en la Universidad Estatal de Carolina del Norte. Otros cargos profesionales ocupados fueron: pasantías en las empresas Mærsk Sealand y Mærsk Logistics, asistente del Consulado de Costa Rica en Chicago, secretaria ejecutiva en empresas comerciales.

Contacto: vpietra@ncsu.edu y vanessapietras@hotmail.com 
